\title{
Microbial transformations of nitrogen, sulfur, and iron dictate vegetation composition in wetlands: a review
}

\author{
Leon P. M. Lamers ${ }^{1}{ }^{*}$, Josepha M. H. van Diggelen ${ }^{2}$, Huub J. M. Op den Camp ${ }^{3}$, Eric J. W. Visser ${ }^{4}$, \\ Esther C. H. E. T. Lucassen ${ }^{1,2}$, Melanie A. Vile ${ }^{5}$, Mike S. M. Jetten $^{3}$, Alfons J. P. Smolders ${ }^{1,2}$ and \\ Jan G. M. Roelofs ${ }^{1}$ \\ 1 Department of Aquatic Ecology and Environmental Biology, Institute for Water and Wetland Research, Radboud University Nijmegen, Nijmegen, Netherlands \\ 2 B-Ware Research Center, Nijmegen, Netherlands \\ ${ }^{3}$ Department of Microbiology, Institute for Water and Wetland Research, Radboud University Nijmegen, Nijmegen, Netherlands \\ ${ }^{4}$ Department of Experimental Plant Ecology, Institute for Water and Wetland Research, Radboud University Nijmegen, Nijmegen, Netherlands \\ ${ }^{5}$ Department of Biology, Villanova University, Villanova, PA, USA
}

\section{Edited by:}

Paul Bodelier, Netherlands Institute of Ecology, Netherlands

Reviewed by:

Brajesh Singh, University of Western Sydney, Australia

Peter Frenzel, MPI for Terrestrial

Microbiology, Germany

*Correspondence:

Leon P. M. Lamers, Department of

Aquatic Ecology and Environmental

Biology, Institute for Water and

Wetland Research, Radboud

University Nijmegen,

Heyendaalseweg 135, 6525 A

Nijmegen, Netherlands.

e-mail:I.lamers@science.ru.nl
The majority of studies on rhizospheric interactions focus on pathogens, mycorrhizal symbiosis, or carbon transformations. Although the biogeochemical transformations of N, S, and $\mathrm{Fe}$ have profound effects on vegetation, these effects have received far less attention. This review, meant for microbiologists, biogeochemists, and plant scientists includes a call for interdisciplinary research by providing a number of challenging topics for future ecosystem research. Firstly, all three elements are plant nutrients, and microbial activity significantly changes their availability. Secondly, microbial oxidation with oxygen supplied by radial oxygen loss from roots in wetlands causes acidification, while reduction using alternative electron acceptors leads to generation of alkalinity, affecting $\mathrm{pH}$ in the rhizosphere, and hence plant composition. Thirdly, reduced species of all three elements may become phytotoxic. In addition, Fe cycling is tightly linked to that of $S$ and P. As water level fluctuations are very common in wetlands, rapid changes in the availability of oxygen and alternative terminal electron acceptors will result in strong changes in the prevalent microbial redox reactions, with significant effects on plant growth. Depending on geological and hydrological settings, these interacting microbial transformations change the conditions and resource availability for plants, which are both strong drivers of vegetation development and composition by changing relative competitive strengths. Conversely, microbial composition is strongly driven by vegetation composition. Therefore, the combination of microbiological and plant ecological knowledge is essential to understand the biogeochemical and biological key factors driving heterogeneity and total (i.e., microorganisms and vegetation) community composition at different spatial and temporal scales.

Keywords: biodiversity, eutrophication, heterogeneity, nutrients, plant-microbe interactions, plants, rhizosphere, toxicity

\section{INTRODUCTION}

Plant ecologists have long been focusing mainly on above-ground processes, while a significant part of the driving mechanisms of ecosystem functioning is taking place below-ground (Waisel et al., 1996). This strongly pleads for studies including biogeochemical transformations in soils and the important interactions between their key players: microorganisms and plants. This paper will focus on the roles of microbial conversions of the elements nitrogen $(\mathrm{N})$, sulfur $(\mathrm{S})$, and iron $(\mathrm{Fe})$, with respect to their major role in the functioning and succession of plant communities in wetlands. The rationale lies in the fact that all three elements can be converted to chemical species that can serve as nutrients, as terminal electron acceptors and electron donors, and can also be toxic. We hope in this review to show the fascinating biogeochemical interactions between plant communities and microbial communities, and encourage microbiologist and plant ecologists to further integrate their disciplines in the hidden half of the ecosystem
(Figure 1). Wetland overall communities (i.e., the integration of micro- and macro-communities) provide excellent examples for this complex interaction playground, the rhizosphere. We define the rhizosphere as that part of the soil where plant roots significantly interact with soil biological and chemical processes, at the scale of $10^{-4} \mathrm{~m}$ or less to $10^{-1} \mathrm{~m}$. One should realize that the root systems of plants can be very large, up to $112 \mathrm{~km} \mathrm{~m}^{-2}$ of soil (Robinson et al., 2003) and reaching a depth between $10^{-3}$ and $10 \mathrm{~m}$ (or even deeper for trees; Canadell et al., 1996). Therefore, a major part of the upper soil of all vegetated wetlands can be defined more or less as a potential rhizosphere. This urges the use of an integrated approach of microbiologists and plant ecologists, in order to understand wetland biogeochemistry, biodiversity, and resilience with respect to ecosystem changes. The purpose of this paper is to show how microbial activity related to the biogeochemical transformation of N, S, and Fe also has profound effects on the activity and competitive strength of plants in wetlands. In 


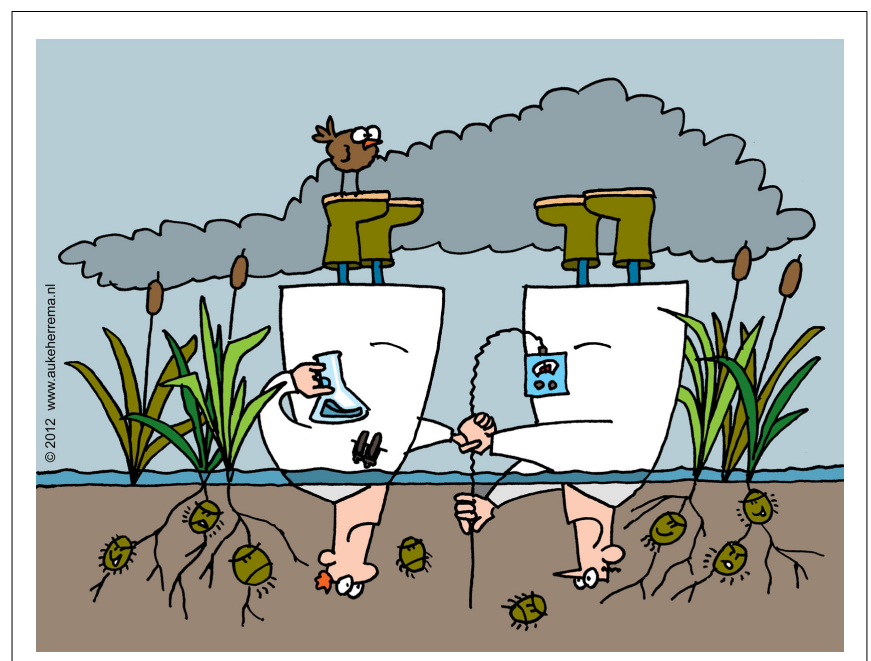

FIGURE 1 | Below-ground scientific collaboration in wetlands: microbiology meets plant ecology. Cartoon by Auke Herrema.

this way, they shape the structure, succession, and biodiversity of vegetation.

\section{HETEROGENEITY IN SOILS DRIVES BIODIVERSITY AND FUNCTIONING}

Unvegetated wetland soils, such as deeper parts of lake sediments or sediments of turbid shallow lakes (with insufficient light for underwater plant photosynthesis) are relatively homogeneous, except for the sediment-water boundary layer that generally shows a steep redox profile related to the successive depletion of terminal electron acceptors (Wetzel, 2001). One of the interesting characteristics of vegetated soils, and particularly of wetland soils, is their heterogeneity in space and time (Paul and Clark, 1989; Conrad and Frenzel, 2002; Bodelier, 2011). Microbiological batch experiments, even those containing multiple organisms, hardly resemble these soils. One of the challenges in microbial ecology is therefore to include this heterogeneity in resources (nutrients, substrates, electron acceptors) and conditions (e.g., oxygenation level, $\mathrm{pH}$ ) under experimentally controlled conditions. Even under apparently stable conditions, the outcome of competition for one or several nutrients may be chaotic (Huisman and Weissing, 1999), but heterogeneity is even more relevant, ecologically speaking, because it facilitates the formation of multiple niches and generates larger fluctuations in conditions over time. As such, heterogeneity strongly affects competition between species (or operational taxonomic units at around species level), and diversity will differ from that under homogeneous conditions. Competitive exclusion, occurring under homogeneous, stable conditions, can be prevented by spatial and temporal heterogeneity, both for microorganisms and for macroorganisms.

In soils with plants (almost all soils in the world), heterogeneity increases as a result of rhizospheric effects (Marschner, 1995) and three-dimensional gradients (changes in concentrations with distance) at the micron-millimeter scale can be very steep. Different consortia of microbial species are present inside roots, on the root surface, and occur at different distances from roots, all of which are related to root exudate concentrations, oxygen availability, nutrient availability, and pH (Brune et al., 2000; Bodelier, 2003; Bodelier et al., 2006). Plant roots even influence soil temperature, with significant effects on microbial activity (Boone et al., 1998). Rhizospheric interactions between microbes and plants have been studied to a large extent with respect to pathogens, mycorrhizal symbiosis, and carbon transformations (e.g., Callaway, 1995; Smith and Smith, 1997; Jones, 1998; Hanson et al., 2000; Whipps, 2001; Gilbert, 2002; Read and Perez-Moreno, 2003).

As a result of heterogeneity, the concentrations of terminal electron acceptors, nutrients, and toxins can differ greatly at even the micro-scale (Bodelier et al., 2006). In redox reactions, the oxidation of organic and inorganic compounds (electron donors) to generate energy has to be coupled to the reduction of electron acceptors, e.g., $\mathrm{O}_{2}, \mathrm{NO}_{3}^{-}, \mathrm{Fe}^{3+}, \mathrm{SO}_{4}^{2-}$. As a result of differences in energy generation, textbooks show a sequential "preference" for the use of electron acceptors, starting with $\mathrm{O}_{2}$. This implies that microorganisms able to use a particular electron acceptor are expected to outcompete organisms using alternative, less favorable electron acceptors. However, small-scale differences in electron acceptor availability in heterogeneous soils explain the co-existence of different microbial groups, without outcompeting one another due to thermodynamic competitive advantage. In addition, the rapid transformation of reduced products by microbial re-oxidation, loss to the atmosphere (e.g., $\mathrm{N}_{2}$ ), or chemical sequestration (e.g., $\mathrm{FeS}_{x}$ ) may lead to favorable thermodynamic conditions that are incomparable to those in closed batch systems.

Changes in plant species composition will strongly affect microbial communities in the rhizosphere. Especially in wetlands, where soils are periodically or constantly flooded or waterlogged, radial oxygen loss (ROL) from plant roots has an extreme impact on rhizospheric microbial communities, locally converting conditions in the wetland soil to those normally found in oxygenated upland soil. Using microelectrodes, Frenzel et al. (1992) showed that rice plants were well able to oxygenate the soil. Oxygen is transported through aerenchyma in the stolons and roots by diffusion or mass flow, and the extent and type of aerenchyma formation differs to a large extent among species (Jackson and Armstrong, 1999; Visser et al., 2000a,b; Voesenek et al., 2006). As a consequence, the spatial pattern of ROL, also strongly varies among wetland species, due to differences in lignin and/or suberin deposits in the exodermis of roots. These deposits act as a barrier to prevent loss of $\mathrm{O}_{2}$ in the upper soil layer and ensure $\mathrm{O}_{2}$ supply to the active root tips (Armstrong, 1978; Laan et al., 1989; Colmer, 2003), and thereby prevent root anaerobiosis (Lambers, 1976; Vartapetian and Jackson, 1997; Jackson and Armstrong, 1999). This means that steep changes in oxygen availability, and hence in microbial communities, will prevail in the rhizosphere, in contrast to anaerobic bulk soil, depending on plant species composition. For this reason, microbial communities in wetland soils may be more diverse than in upland soils. The physiological ability to oxidize rhizospheres differs among plant species, which may not only facilitate conspecifics but also heterospecifics (Callaway, 1995). Next to this spatial heterogeneity, there will also be a strong temporal heterogeneity in the rhizosphere due to changes in temperature, plant presence, plant activity, and water table. Particularly in riparian wetlands, where water tables fluctuate frequently, both resource 
availability and conditions can vary widely, providing challenges and opportunities for microbes.

\section{NUTRIENT CYCLING AND UPTAKE IN THE RHIZOSPHERE}

For both heterotrophic and autotrophic organisms including plants, sufficient nutrient acquisition is essential to transform the carbon acquired into growth and reproduction and to safeguard the fitness of their populations. The rates of transformation of dead organic material into simple organic compounds and minerals, carried out by fauna and microorganisms, strongly determine the growth rates of plants. At high nutrient availability, fastgrowing and highly competitive species will generally dominate at the expense of slow-growing species and monopolize light and space. As the quality of the dead organic matter strongly differs between plant species, decomposition (carbon mineralization) and the mineralization of the macronutrients $\mathrm{N}, \mathrm{P}$, potassium $(\mathrm{K})$, and $\mathrm{S}$, and of micronutrients including $\mathrm{Fe}$ and manganese $(\mathrm{Mn})$, will depend on the species composition. Higher nutrient concentrations in dead material may stimulate mineralization rates, in this way providing a positive feed-back (Hobbie, 1992; Aerts and Chapin, 2000). This will, however, depend on the nature of nutrient limitation of the decomposition rate, which can be limited either by $\mathrm{N}, \mathrm{P}$, or both. Although the C: $\mathrm{N}$ ratio of organic matter has traditionally been used as a quantitative indication of (potential) decomposition rates, the C:P ratio may be a better indicator for locations that show a high availability of $\mathrm{N}$, e.g., as a result of high atmospheric $\mathrm{N}$ input. However, studies on the effect of organic matter quality on decomposition and nutrient mineralization rates still show much inconsistency (Kalbitz et al., 2000). Note that rates of vegetation growth and microbial decomposition do not necessarily have to be limited by the same element. Plants are able to actively forage for nutrients, leading to selective root placement at spots enriched with nutrients (Hutchings and De Kroon, 1994; Hodge, 2004). In this way, not only nutrient availability and its heterogeneity, but also traits and plasticity of plants with respect to root foraging strategies will drive below-ground competition, vegetation diversity, and biomass production (De Kroon et al., 2012). This means that there is a complex interaction between plant species composition and microbial communities including fungi, bacteria, and archaea. For technical reasons related to root sampling, many interesting characteristics of this hidden, but very important aspect of plant communities (Waisel et al., 1996) are yet to be discovered. New techniques including soil scanning in largescale rhizotrons (Figure 2) enable an underground view on plant communities, which can be coupled to, e.g., fluorescence in situ hybridization (FISH) techniques visualizing the locations of different microbial groups or species, microarrays to rapidly check for known sequences, polymerase chain reaction (PCR) based community analyses and metagenomics (full community genomics), to gain insight into rhizospheric microbe-plant communities and interactions. Next generation DNA sequencing technologies can be expected to make rhizosphere community analyses much faster, cheaper, and easier, enabling for instance multiple comparisons between different plant species in one vegetation type, and between conspecifics under different environmental conditions.

The three elements that we focus on here, N, S, and Fe, all are essential nutrients for the metabolism and growth of both plants

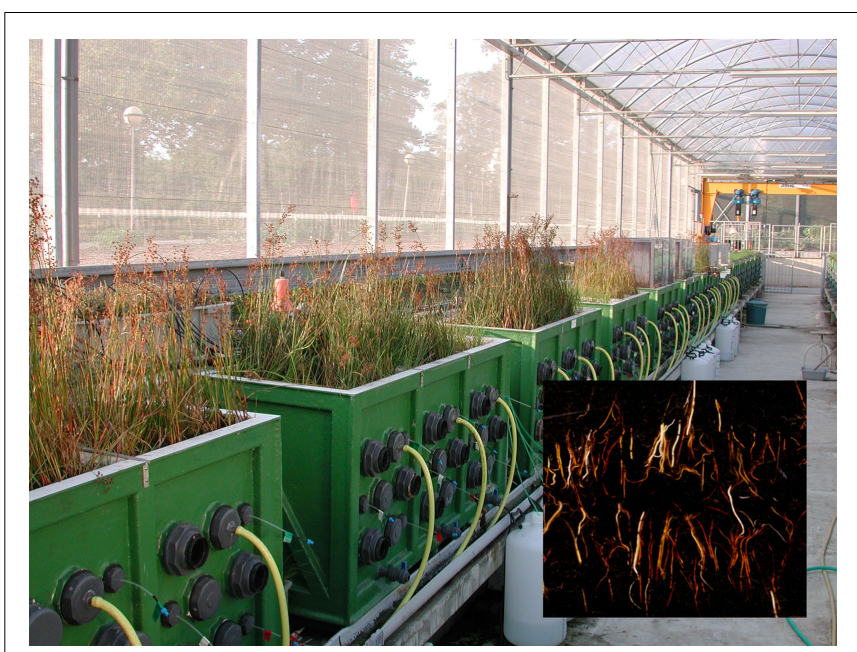

FIGURE 2 |The Nijmegen Phytotron facility, and a scan image of the root scanner in transparent tubes in the soil (inlay).

and microorganisms. These elements are predominantly taken up by plants from the soil via the roots, as only few plant species may take up high amounts of nutrients via the leaves. An exception are aquatic macrophytes that take up nutrients from the surface water, especially when soil concentrations are low or when the plants lack roots. On a quantitative base, $\mathrm{N}$ is the most important macronutrient (Marschner, 1995; Larcher, 2003), essential for the synthesis of amino acids, amines, and peptides (including proteins). As the availability and uptake of this element is a major factor limiting biomass production in many ecosystems (Vitousek and Howarth, 1991; Larcher, 2003), its availability and mobility are important drivers of species composition and biodiversity. Enhanced $\mathrm{N}$ availability changes biodiversity and heterogeneity, both above-ground and below-ground. Due to selective root placement, spots enriched in $\mathrm{N}$ contain more roots. For plants including Fabaceae (formerly called Leguminosae), the symbiotic relation with rhizobial strains of a variety of genera of Proteobacteria including Rhizobium, is of vital importance for atmospheric dinitrogen $\left(\mathrm{N}_{2}\right)$ fixation in soils that are low in N (Dakora and Phillips, 2002). The symbionts are attracted by the exudation of phenolics and aldonic acids from roots. For non-Fabaceous plants including the tree and shrub genera Alnus, Casuarina, Ceanothus, and Myrica, atmospheric $\mathrm{N}_{2}$ is supplied by Frankia Actinobacteria. The cyanobacterial symbiont Anabaena provides atmospheric $\mathrm{N}$ to waterferns (Azolla spp.). The yearly amounts of nitrogen provided by these symbionts can be as high as $100 \mathrm{~kg} \mathrm{Nha}^{-1}$ or more, which is similar to the highest anthropogenic airborne $\mathrm{N}$ fluxes reported. As a result, these plant species have a strong competitive advantage over other species under $\mathrm{N}$ limitation, especially under riparian conditions with coupled nitrification (during dry episodes) and denitrification (of generated nitrate, during wet episodes). Note that $\mathrm{N}$ limitation will also occur when $\mathrm{P}$ levels are high and $\mathrm{P}$ is no longer limiting biomass production, which explains the dominance of the AzollaAnabaena complex and free-living $\mathrm{N}$-fixing aquatic cyanobacteria under high $\mathrm{P}$ loads (Lamers et al., 2002b). In addition to the above-mentioned "usual suspects," a large phylogenetic variety of 
free-living and symbiotic microorganisms including other Proteobacteria, Archaea, and Verrucomicrobia is now known to be able to fix atmospheric dinitrogen gas (Kneip et al., 2007; Khadem et al., 2010; Reed et al., 2011).

Although less frequently, low availability of S may also hamper plant growth (Dijkshoorn and van Wijk, 1967; Marschner, 1995). Like N, S is a vital constituent for protein structuring. While N and $\mathrm{S}$ are macronutrients, $\mathrm{Fe}$ is considered a micronutrient (average $\mathrm{N}: \mathrm{S}:$ Fe in plant shoots is 500:15:1 on a molar basis; Marschner, 1995). The availability of Fe is essential for photosynthesis, as it is a cofactor for chlorophyll synthesis. During anaerobic soil conditions in wetlands, $\mathrm{Fe}$ is mainly present as $\mathrm{Fe}^{2+}$ as a result of microbial Fe reduction, and its mobility and availability are relatively high. This may even lead to Fe toxicity (see below). During aerobic conditions, $\mathrm{Fe}$ is oxidized to $\mathrm{Fe}^{3+}$ and a large part precipitates as hydroxides and oxyhydroxides, and Fe acquisition becomes hampered. To acquire Fe from Fe(III) compounds, plants have developed different mechanisms through evolution that facilitate uptake (Jones, 1998; Dakora and Phillips, 2002; Hell and Stephan, 2003). Graminaceous plants exude metal chelating amino acids called phytosiderophores, which are also important for the uptake of other micronutrient metals such as $\mathrm{Mn}$, zinc ( $\mathrm{Zn}$ ), and copper $(\mathrm{Cu})$. Non-graminaceous monocots, dicots, and bacteria release protons in the rhizosphere, or exude reducing and chelating compounds such as phenolics (Marschner, 1995; Schmidt, 1999). Soil Fe is, however, also strongly linked to phosphorus (P) availability, as both elements form a variety of chemical complexes, making $\mathrm{P}$ less available. Therefore, mechanisms to increase Fe availability may also be regarded as P mobilizing mechanisms (Bolan, 1991), next to the infection with mycorrhizal fungi.

Plants and microbes may compete for N, S, and P, depending on their relative availabilities (Hobbie, 1992), and competition models should therefore include this competition, yet few studies have. Especially at low nutrient levels, microbial uptake may significantly hamper nutrient uptake by plants, and hence reduce growth rates. As a result, they may even be able to increase the competitive advantage of slow-growing plant species and influence biodiversity. Not only competition at short-term, but also release rates from the microbial pool should be accounted for. As an example, selective root placement may be much slower than microbial colonization of a nutrient-rich patch, but subsequent release of $\mathrm{N}$ and $\mathrm{P}$ from the microbial pool can be effectively intercepted by these roots (Hodge et al., 2000).

\section{BELOW-GROUND CARBON TURNOVER}

The die-off of plant rhizomes, roots and above-ground litter, and their shredding by macro-, meio-, and microfauna strongly determines the availability of organic substrates for fermentation and the availability of organic electron donors (e.g., lactate, acetate, succinate, propionate) for a variety of microbial anaerobic and aerobic redox processes. The decomposability of dead plant material greatly varies between species, not only due to varying $\mathrm{N}$ and $\mathrm{P}$ concentrations and $\mathrm{pH}$, but also as a result of varying concentrations of recalcitrant compounds such as lignin, and of potentially toxic secondary metabolites including other phenolic compounds and alkaloids. Consequently, plant species composition of a vegetation type has a great impact on decomposition rates and nutrient cycling (Hobbie, 1992). Decomposition rates of graminoid species such as grasses (Gramineae) and sedges (Cyperaceae) are, for instance, much faster than those of peat mosses (Sphagnum), which contain high concentrations of polyphenolics and pectin-like polysaccharides (Verhoeven and Toth, 1995; Hajek et al., 2011). Even though net primary production of Sphagnum can, for instance, not compete with the highest production rates of vascular plants, low decomposition rates may still lead to fast peat accumulation. Long term accumulation rates may, however, differ from present-day rates depending on changing balances between production and decay rates (Clymo et al., 1998; Wieder et al., 2009). Next to species effects on dead organic matter (OM), microbial breakdown can also vary within one particular species. High atmospheric deposition rates of $\mathrm{N}$ may, for instance, decrease the concentration of polyphenols in Sphagnum peat and concomitantly increase decomposition rates, with consequences for net $\mathrm{C}$ sequestration (Bragazza and Freeman, 2007). The actual decomposition rates are regulated by the interaction between the nutrient $(\mathrm{N}, \mathrm{P})$ concentrations in the $\mathrm{OM}$, recalcitrant or toxic compounds, and soil conditions. Peat accumulation (i.e., sequestration of atmospheric C) depends on the precarious balance between production and decomposition, and high production rates are generally coupled to higher decomposition rates as a result of organic matter quality.

Phenolic compounds have been shown to block the decomposition in peatlands to a large extent by inhibiting the activity of various crucial microbial enzymes in carbon transformation (Freeman et al., 2001). Oxygen intrusion during low water tables activates phenol oxidase activity, lowering phenol concentrations, and thereby stimulating overall decomposition. In addition, oxygen acts as the most favorable electron acceptor, stimulating decomposition rates by a factor of two or more. ROL from roots can be expected to have the same impact. A spectacular example is the large-scale rhizosphere oxidation by the vascular peatland plant species Astelia pumila and Donatia fascicularis, that may appear miniscule in stature above-ground, but possess extensive root systems that strongly stimulate decomposition rates to a depth of more than $1 \mathrm{~m}$ (Fritz et al., 2011). As a result of low nutrient levels in the pristine Patagonian peatlands where these species occur, carbon is preferentially allocated to root production. The strong soil oxygenation also nullifies methane emission by the inhibition of methanogenic communities and/or the stimulation of methanotrophic communities. In oligotrophic lakes, small-leaved (so-called isoetid) species with relatively large root systems have a similar effect on decomposition rates (Smolders et al., 2002). The growth rates of facultatively aerobic, heterotrophic bacteria including Pseudomonas chlororaphis are significantly enhanced under flooded conditions by ROL of emergent macrophytes such as Glyceria maxima and Oryza sativa (Bodelier et al., 1997, 1998), demonstrating the strong effect root systems may have on microbial composition and processes.

\section{MICROBIAL SOIL ACIDIFICATION AFFECTS PLANTS}

The cycling of $\mathrm{N}, \mathrm{Fe}$, and $\mathrm{S}$ in the soil is not only determined to a large extent by microbial activity, but also by uptake, release, and transformations of species of these elements due to root activity. 
Plants can change the $\mathrm{pH}$ of the rhizosphere by the exudation of protons, organic acids, $\mathrm{HCO}_{3}^{-}$, and $\mathrm{OH}^{-}$(Dakora and Phillips, 2002). By the excretion of root exudates, acids, and oxygen, plants control microbial resource availability, concentrations of oxygen as a potential toxin and electron acceptor, and $\mathrm{pH}$ in the rhizosphere. As a result of ROL or temporary water table draw-down (e.g., in riparian wetlands), $\mathrm{pH}$ can be strongly lowered due to microbial and chemical oxidation of N, S, Fe, generating acid (oxygen literally means acid generator). This may even lower the availability and uptake of redox-sensitive metals (e.g., Fe, Mn) or increase the availability and uptake of $\mathrm{pH}$-sensitive metals that are not redox-sensitive (e.g., aluminum, $\mathrm{Al}$ ). The $\mathrm{pH}$ change by the oxidation of ammonium and nitrite by nitrifying proteobacteria (e.g., the genera Nitrosomonas, Nitrosospira, Nitrobacter, Nitrospira) or crenarchaea, reduced $\mathrm{S}$ including sulfides to $\mathrm{S}$ and $\mathrm{SO}_{4}^{2-}$ by $\mathrm{S}$ oxidizing proteobacteria (e.g., Beggiatoa, Thiobacillus), and ferrous iron to ferric iron (e.g., Gallionella ferruginea) not only influences microbial communities, but also plant communities. Most plant species are sensitive to low soil $\mathrm{pH}$ values $(\mathrm{pH}<5)$, not only by direct effects on membrane physiology, but also indirectly, by $\mathrm{Al}$ toxicity and by the impairment of the uptake of potassium $(\mathrm{K})$, calcium (Ca), and magnesium (Mg; Marschner, 1995). Although $\mathrm{Al}$ is one of the most common metals in soils, its toxicity is completely dependent on its mobility, which is strongly regulated by $\mathrm{pH}$. The $\mathrm{pH}$ in the rhizosphere may be much lower than that of the bulk soil. The regulation of $\mathrm{pH}$ is a combined effect of ROL activity, rhizospheric oxygen consumption, proton loss by roots (e.g., for $\mathrm{NH}_{4}^{+}$uptake), availability of electron donors like $\mathrm{N}, \mathrm{Fe}$, and $S$, and the acid neutralizing capacity (ANC) of the soil. Depending on the $\mathrm{pH}$ range (from 8 down to 3 ), $\mathrm{ANC}$ is provided by bicarbonate and carbonate, exchange of base cations such as $\mathrm{Ca}$ and $\mathrm{Mg}$ at soil cation exchange sites, and the dissolution of $\mathrm{Fe}$ and Al-oxides and hydroxides and silicates. Where bulk soil will be buffered under anaerobic conditions by the microbial reduction of $\mathrm{N}$, manganese $(\mathrm{Mn}), \mathrm{Fe}$, and $\mathrm{S}$ (all generating alkalinity, i.e., consuming $\mathrm{H}^{+}$), local oxidation by ROL will reverse this process. As such, high ROL activity can mimic the lowering of the water table in wetlands at a very local, but crucial scale. Under flooded or waterlogged conditions, most bulk soils are buffered around pH 6-6.5 by the $\mathrm{CO}_{2}-\mathrm{HCO}_{3}^{-}$buffering mechanism. As microbial decomposition (generating inorganic carbon) is generally coupled to microbial mineralization of $\mathrm{P}$ and $\mathrm{N}$, microbially derived $\mathrm{HCO}_{3}^{-}$ concentrations can even be used as a proxy for nutrient availability in freshwater and marine soils (Van der Heide et al., 2010).

\section{NITROGEN: A MOBILE NUTRIENT THAT MAY BECOME TOXIC}

Either the availability of electron donors or the availability of electron acceptors determines the nature and rates of microbial redox reactions in wetland soils. In the rhizosphere of plants showing high rates of ROL, oxidation of $\mathrm{N}, \mathrm{S}$, and Fe takes place (Bodelier, 2003). This implies that there will be a strong gradient in microbial communities at the micro-scale, from close to the roots toward the bulk soil. Ammonium $\left(\mathrm{NH}_{4}^{+}\right)$produced in the bulk soil is oxidized to nitrate/nitrite $\left(\mathrm{NO}_{3}^{-} / \mathrm{NO}_{2}^{-}\right)$by $\mathrm{N}$ oxidizing communities, including Crenarchaeota (Leininger et al., 2006; Jetten, 2008). Such local redox processes create a variety of $\mathrm{N}$ species, which have effect on plant performance. Although plants can use oxidized inorganic $\mathrm{N}\left(\mathrm{NO}_{3}^{-}\right)$, reduced inorganic $\mathrm{N}\left(\mathrm{NH}_{4}^{+}\right)$, and organic $\mathrm{N}$ (amino acids) as $\mathrm{N}$ source, plants adapted to soils with low $\mathrm{pH}$ and low redox potential prefer $\mathrm{NH}_{4}^{+}$(Marschner, 1995). For plants adapted to soils with higher $\mathrm{pH}$, it has been shown that $\mathrm{NH}_{4}^{+}$can be toxic to a variety of plant species, mainly by leading to nutrient imbalances ( $\mathrm{K}, \mathrm{Mg}$ deficiency) or internal acidification in roots. Aquatic macrophytes prefer either $\mathrm{NH}_{4}^{+}$or $\mathrm{NO}_{3}^{-}$, depending on the $\mathrm{pH}$ of the surface water where the species mainly occurs (Roelofs et al., 1984). Most rooting wetland plants are evolutionary adapted to $\mathrm{NH}_{4}^{+}$uptake, although $\mathrm{NH}_{4}^{+}$may also be taken up after rhizospheric oxidation to $\mathrm{NO}_{3}^{-}$. Plants of riparian wetlands, however, are known to face problems at a high $\mathrm{NH}_{4}^{+}: \mathrm{NO}_{3}^{-}$ratio in acidified soil during lower water tables in the growing season (Lucassen et al., 2003; Van den Berg et al., 2005). Increased anthropogenic $\mathrm{NH}_{4}^{+}$inputs, as a result of ammonia $\left(\mathrm{NH}_{3}\right)$ emissions in regions with intensive cattle breeding, have for this reason led to the decrease of sensitive species and loss of biodiversity (Stevens et al., 2011). In riparian wetlands with a low soil ANC, acidification due to high $\mathrm{N}$ and $\mathrm{S}$ inputs increases the $\mathrm{NH}_{4}^{+}: \mathrm{NO}_{3}^{-}$ratio due to a decrease of the activity of $\mathrm{N}$ oxidizers. In soils that have been acidic for longer time, nitrification rates may be higher due to the development of acid-resistant $\mathrm{N}$ reducers (De Boer and Kowalchuk, 2001). In soils with a high $\mathrm{pH}(>8.5)$, a significant proportion of $\mathrm{NH}_{4}^{+}$(ammonium) is present as ammonia $\left(\mathrm{NH}_{3} ; \mathrm{pK}=9.25\right)$, which is highly toxic to plant roots (Schenk and Wehrmann, 1979). Similarly, high $\mathrm{pH}$ values of surface water, e.g., as a result of aquatic photosynthesis $(\mathrm{pH}>10)$, can lead to $\mathrm{NH}_{3}$ toxicity to submerged vegetation and fauna in $\mathrm{N}$ loaded aquatic systems (Thurston et al., 1981). The actual toxicity of $\mathrm{N}$ depends on its accumulation in plant tissues and becomes higher under P-limited conditions due to extra accumulation. By the production of $\mathrm{N}$-rich free amino acids, plants are able to detoxify excess internal $\mathrm{N}$, but only to a certain level (Tomassen et al., 2003).

It has been shown that increased availability of $\mathrm{NO}_{3}^{-} / \mathrm{NO}_{2}^{-}$by increased nitrification rates in the rhizosphere may raise denitrification in the anaerobic bulk soil the root zone with sufficient oxygen supply (Reddy et al., 1989; Arth et al., 1998). In addition, higher rates of anaerobic ammonium oxidation (anammox) or dissimilatory nitrate reduction to ammonium (DNRA) can be expected to increase at the oxic/anoxic interface (Jetten et al., 1998; Burgin and Hamilton, 2007; Hu et al., 2011). The uptake of $\mathrm{NH}_{4}^{+}$or $\mathrm{NO}_{3}^{-}$by plant roots may, however, lower denitrification rates in freshwater and marine wetlands by reducing the $\mathrm{N}$ pool (Bodelier et al., 1996; Welsh et al., 2000). For vegetation, the rates of these $\mathrm{N}$ conversions are important, as most of the gaseous reaction products $\left(\mathrm{N}_{2}\right.$ and $\left.\mathrm{N}_{2} \mathrm{O}\right)$ leave the soil compartment and are no longer available (except through microbial $\mathrm{N}_{2}$ refixation). $\mathrm{N}_{2}$ production by $\mathrm{N}$ reduction is strongly reduced by lowering of $\mathrm{pH}$ from 7 to 4 , but the (net) $\mathrm{N}_{2} \mathrm{O}: \mathrm{N}_{2}$ production ratio shows an exponential increase in this transect as a result of the inhibition of $\mathrm{N}_{2} \mathrm{O}$ reduction at low $\mathrm{pH}$ (Van den Heuvel et al., 2011). The heterogeneity with respect to $\mathrm{N}_{2} \mathrm{O}$ emission rates seems to be explained by differences in soil structure affecting gas transport rather than by microbial composition (Van den Heuvel et al., 2009), and probably also by vegetation composition. As such, $\mathrm{N}$ biogeochemistry is far more complex and variable than that of $\mathrm{P}$, which is only released to the atmosphere in very small quantities as phosphine (Wetzel, 
2001). In riparian wetlands, the water table strongly dominates $\mathrm{N}$ cycling and availability. $\mathrm{N}$ dynamics are influenced by microbial activity at all spatial scales, from the rhizosphere (plant $\mathrm{N}$ availability) through the community level (competition between species under $\mathrm{N}$ limitation) to the ecosystem level ( $\mathrm{N}$ exchange with the surroundings, including the atmosphere). In addition, there is high variability at the temporal scale, mostly coupled to seasonal change and water table fluctuations (Neubauer et al., 2005).

High inputs of $\mathrm{NO}_{3}^{-}$in wetland soils are known to inhibit microbial Fe reduction for thermodynamical reasons (hence $\mathrm{N}$ reducers outcompete Fe reducers). This may not only lead to Fe deficiency in vegetation (Smolders and Roelofs, 1993), but also to reduced mobilization and availability of $\mathrm{P}$ in the rhizosphere (Lucassen et al., 2004). A significant part of soil P is sequestered by $\mathrm{Fe}$, and ferrous $\left(\mathrm{Fe}^{2+}\right)$ iron phosphate complexes are more soluble than ferric $\left(\mathrm{Fe}^{3+}\right)$ iron phosphate compounds (Richardson, 1985; Scheffer and Schachtschabel, 2002). For the vegetation involved, increased $\mathrm{N}$ inputs may have contrasting effects, depending on the actual nutrient limiting the rate of biomass production. For $\mathrm{N}$-limited systems, biomass production will increase and plant biodiversity will generally decrease by out-competition of slowgrowing species. For P-limited systems, productivity may become lower and biodiversity become increased as a result of lower $\mathrm{Fe}$ reduction rates, leading to lower $\mathrm{P}$ availability. The latter is the reason why P-loaded lakes have even been treated with $\mathrm{NO}_{3}^{-}$in order to change the eutrophic state, dominated by algae, to a less eutrophic state in which underwater vegetation receives more light (Ripl, 2010).

\section{TOXICITY OF S AND Fe, AND THEIR INTERACTIONS WITH P AVAILABILITY}

Fe reduction by bacteria, including sulfate reducing bacteria (e.g., Geobacter sulfurreducens), and archaea converts ferric compounds into ferrous iron (Lovley and Phillips, 1988; Coleman et al., 1993; Lovley et al., 2004; Weiss et al., 2004), which is much more mobile and is preferentially taken up by plants. The reduction of ferric iron, produced as a result of ROL, may suppress other anaerobic processes including methanogenesis (Frenzel et al., 1999). Although Fe is an essential micronutrient, high levels of Fe may become phytotoxic. This toxicity may even become visible aboveground as necrotic spots on the leaves of wetland plants (Lucassen et al., 2000). The oxidation of Fe by ROL may detoxify Fe due to the microbial or chemical precipitation of Fe hydroxides in the soil (Armstrong, 1978; Bienfait, 1989). However, excess Fe in combination with relatively low ROL can generate problems for plants due to Fe plaque formation on the root surface or by Fe deposition in the root apoplast (Taylor et al., 1984; Smolders and Roelofs, 1996; Emerson et al., 1999). These incrustations include Fe oxides (e.g., ferrihydrite), Fe oxyhydroxides (e.g., goethite), Fe carbonates (e.g., siderite), and Fe phosphates (e.g., vivianite), microbially derived organic-metal complexes, bacterial biofilms, and co-deposition of other metals such as manganese, copper, zinc, and lead (Batty et al., 2000; Hansel et al., 2001). Root physiology can be negatively affected by this plaque that acts as a physical barrier and interferes with P metabolism (Snowden and Wheeler, 1995). An interesting aspect of Fe hydroxide precipitation on microbes is the fact that they act as nanowires shuttling electrons in microbial communities
(Lovley, 2006; Rabaey et al., 2007), and also electrically connect them to plant roots.

The activity of sulfate reducing prokaryotes (SRP) is also of high relevance to vegetation development. Dissimilatory sulfate reducers include both Bacteria (e.g., Desulfovibrio, Desulfobacter) and Archaea (e.g., Archaeoglobus) producing sulfide $\left(\mathrm{H}_{2} \mathrm{~S}\right)$. Whereas oxidized states of $\mathrm{S}\left(\mathrm{SO}_{4}^{2-}, \mathrm{S}\right)$ are hardly toxic to plants, $\mathrm{H}_{2} \mathrm{~S}$ is highly toxic by inhibiting the activity of cytochrome $\mathrm{c}$ oxidase in mitochondria, leading to a subsequent blocking of energy production in roots, and by inhibiting other metal containing enzymes (Koch et al., 1990; Raven and Scrimgeour, 1997). The rhizospheric oxidation of $\mathrm{S}$ (Figure 3 ) by microbial activity of $\mathrm{S}$ oxidizers including Beggiatoa detoxifies $\mathrm{H}_{2} \mathrm{~S}$, and $\mathrm{ROL}$ activity of plants will therefore moderate the sensitivity of plants to sulfide. All three $\mathrm{pH}$-dependent species of sulfide $\left(\mathrm{H}_{2} \mathrm{~S}, \mathrm{HS}^{-}\right.$, and $\mathrm{S}^{2-}, \mathrm{pK}_{1}=7.2$; $\left.\mathrm{pK}_{2}=13.7\right)$ seem to be equally toxic to plants, but for most anaerobic soils the gaseous $\mathrm{H}_{2} \mathrm{~S}$ will be prevailing due to $\mathrm{HCO}_{3}^{-}-\mathrm{CO}_{2}$ buffering around $\mathrm{pH}$ 6-6.5. For marine wetlands receiving sufficient organic matter to keep electron donor concentrations high, $\mathrm{H}_{2} \mathrm{~S}$ production affects the growth of marine and brackish water macrophytes in the millimolar range. The phytotoxin is known to hamper the establishment and growth of the two main mangrove genera Avicennia and Rhizophora (McKee et al., 1988) and of seagrasses including Thalassia testudinum and Zostera marina (Frederiksen et al., 2006; Koch et al., 2007; Holmer et al., 2009). Fluctuations in ROL of seagrass plants lead to low $\mathrm{H}_{2} \mathrm{~S}$ concentrations during daytime and increased concentrations during nighttime. At the end of the growing season decreasing ROL, higher microbial $\mathrm{O}_{2}$ consumption and $\mathrm{H}_{2} \mathrm{~S}$ toxicity in concert induce the die-off of vegetation in brackish wetlands (Azzoni et al., 2001).

Although S concentrations are generally lower in freshwater wetlands, high input rates due to volcanic activity or other geological conditions, and as a result of $S$ pollution of the atmosphere, groundwater, and surface water have raised $\mathrm{SO}_{4}^{2-}$ concentrations at a global scale. In anaerobic freshwater wetland soils, $\mathrm{SO}_{4}^{2-}$ reduction may therefore become a dominant process next to $\mathrm{Fe}$ reduction (Lamers et al., 1998), while its rate can be determined by the availability of either electron donors or $\mathrm{SO}_{4}^{2-}$ (Lamers et al., 2002a). A recent review showed that up to $50 \%$ of the anaerobic decomposition in freshwater wetlands can be attributed to $\mathrm{SO}_{4}^{2-}$ reduction (Pester et al., 2012). Sulfide concentrations in the range of $10-100 \mu \mathrm{mol} \mathrm{L}^{-1}$ are known to be toxic to the roots of freshwater plants (Tanaka et al., 1968; Armstrong et al., 1996; Smolders and Roelofs, 1996; Lamers et al., 1998; Geurts et al., 2009). Like for marine plants, $\mathrm{H}_{2} \mathrm{~S}$ toxicity to roots can be prevented by the activity of sulfur bacteria using $\mathrm{O}_{2}$ from the roots (Joshi and Hollis, 1977). In addition, volatile $\mathrm{S}$ compounds including $\mathrm{H}_{2} \mathrm{~S}$ and, after its methylation, dimethylsulfide, and methanethiol are released to the atmosphere (Lomans et al., 2002). As the thermodynamical characteristics of Fe reduction and $S$ reduction do not differ very much, these conversions take place in the same soils, and $\mathrm{FeS}_{x}$ precipitation occurs (Lamers et al., 2002a). By this sequestration the concentration of both potential phytotoxins is reduced (Van der Welle et al., 2006), and plants may even become Fe deficient (Smolders and Roelofs, 1993).

Already in the 1950s of the former century, the prominent role of $\mathrm{S}$ in aquatic nutrient biogeochemistry was described (Ohle, 


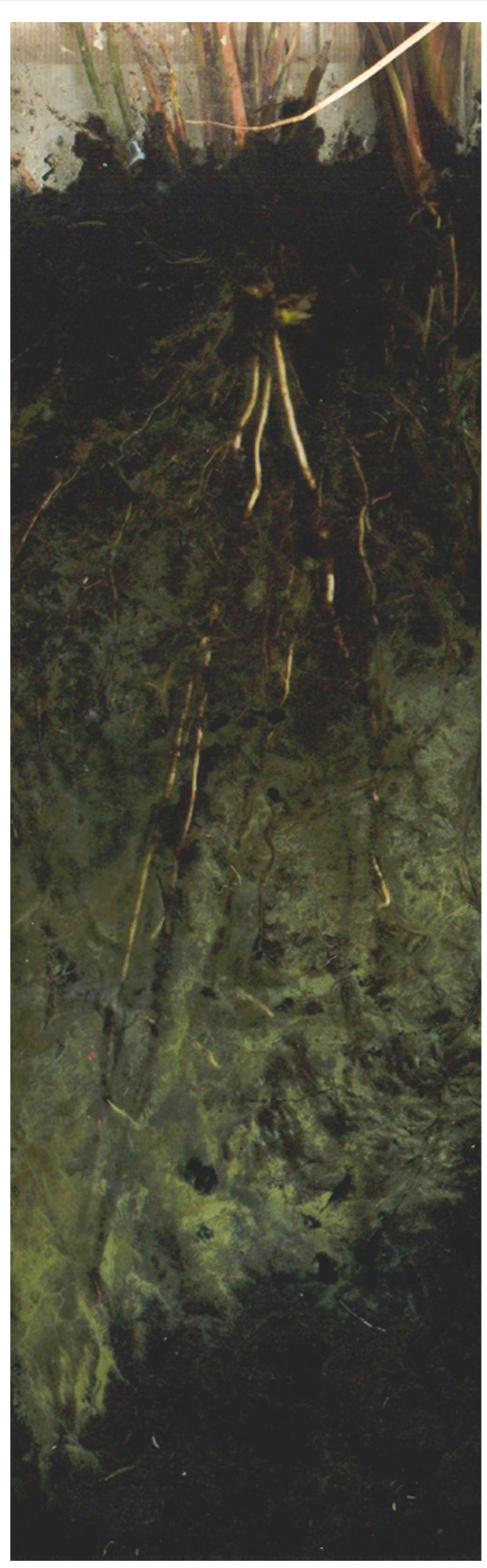

FIGURE 3 | Radial oxygen loss (ROL) of Juncus acutiflorus is shown by the oxidation of added $\mathrm{H}_{2} \mathrm{~S}$ in an anaerobic rhizotron with living plants and natural organic wetland soil. This was confirmed by the use of oxygen microelectrodes. Yellow-whitish haloes of $S^{0}$ and $S$ precipitates have been formed by microbial S oxidation (Lamers and Janssen, unpublished results).
1954). As $\mathrm{SO}_{4}^{2-}$ will serve as a terminal electron acceptor, it will speed up overall anaerobic decomposition. Increased inputs of $\mathrm{SO}_{4}^{2-}$ may additionally mobilize $\mathrm{Fe}$ bound $\mathrm{P}$ in the soil, due to its reduction to $\mathrm{H}_{2} \mathrm{~S}$ competing for Fe binding sites (Sperber, 1958; Caraco et al., 1989; Roden and Edmonds, 1997; Lamers et al., 1998; Smolders et al., 2006) or mobilization of P from polyphosphates by sulfur bacteria (Golterman, 2001). Whether or not sulfate-induced eutrophication occurs, depends on the levels of $\mathrm{P}$ in the sediment and its type of binding (Lamers et al., 2002a; Geurts et al., 2008; Loeb et al., 2008).

The large spatial and temporal heterogeneity in $\mathrm{O}_{2}$ supply (as determined by the balance between local ROL and local oxygen consumption) enables the coupling of oxidation and reduction of the same element $(\mathrm{S}, \mathrm{Fe}, \mathrm{N})$ at a small-scale in the rhizosphere. In this way, consortia of microorganisms using the same element can coexist in wetland soils, but the directions of the transformations are governed by plant physiology and soil characteristics.

In addition to the use of organic electron donors, the reduction of one of the three elements can be coupled to the oxidation of the other (chemolithotrophy). Sulfide, both dissolved and as $\mathrm{FeS}_{x}$ deposits in the soil can be used as an electron donor by proteobacteria such as Thiobacillus denitrificans coupled to the use of $\mathrm{NO}_{3}^{-}$(Haaijer et al., 2006, 2007; Burgin and Hamilton, 2008). Even in peat soils rich in organic compounds, $\mathrm{NO}_{3}^{-}$pulses are still able to stimulate to chemolithotrophic denitrification while organotrophic denitrification rates were very high (Lamers, unpublished results). For plants, this means that the detoxification of sulfide extends beyond the direct influence of ROL, and that S-rich situations may show lower $\mathrm{N}$-availability. At the landscape scale, $\mathrm{N}$ pollution of the catchment will mobilize $\mathrm{S}$ from subsoil $\mathrm{FeS}_{x}$ deposits, and the resulting $S$ pollution of groundwater will lead to $P$ pollution in wetlands where this polluted water is discharged. In this way, there is a microbial " $\mathrm{S}$ bridge" between $\mathrm{N}$ and $\mathrm{P}$ at this hydrological scale (Smolders et al., 2010). In wetland soils, partial $\mathrm{H}_{2} \mathrm{~S}$ oxidation to $\mathrm{S}^{0}$ and pyrite $\left(\mathrm{FeS}_{2}\right)$ can also be coupled to Fe reduction (Thamdrup et al., 1994), with consequences for the availability and toxicity of both elements to plants, and for the availability of $P$.

\section{GLOBAL CHANGES OF N, S, AND Fe BIOGEOCHEMISTRY}

As a result of anthropogenic forcing, the input of all three elements, $\mathrm{N}, \mathrm{S}$, and $\mathrm{P}$, into wetlands has strongly changed at a global scale (Schlesinger, 1997; Vitousek et al., 1997). As a result of urbanization, industrialization, and intensive farming, surface waters of many wetlands have become polluted by $\mathrm{N}$ and $\mathrm{P}$ (Carpenter et al., 1998). In contrast to $\mathrm{P}$, increased $\mathrm{N}$ inputs $\left(\mathrm{NO}_{x}\right.$ and $\left.\mathrm{NH}_{y}\right)$ are also the result of atmospheric deposition, which has strongly increased in industrialized regions and in regions with intensive farming (Vitousek et al., 1997; Bobbink et al., 1998). Whereas S deposition rates in Europe have been reduced by $80-90 \%$ as a result of legislation, they are strongly increasing in other parts of the world. In fast-developing regions such as Asia (particularly China), $\mathrm{SO}_{x}$ emissions may soon equal the combined emissions of North America and Europe as a result of the large-scale use of coal as a fuel (Shah et al., 2000). In addition to $\mathrm{N}$ and $\mathrm{S}$ pollution, many wetlands have been drained for land use change (Lamers et al., in press), which has not only resulted in the loss of wetlands, but also 
in significant changes in the hydrochemistry of wetlands that have not suffered from complete dehydration. Lowering of groundwater tables, also due to the extraction of drinking water and industrial process water, has decreased the influence of groundwater in wetlands to a large extent. As a result, the discharge of anaerobic, Fe-rich groundwater has decreased. This means that

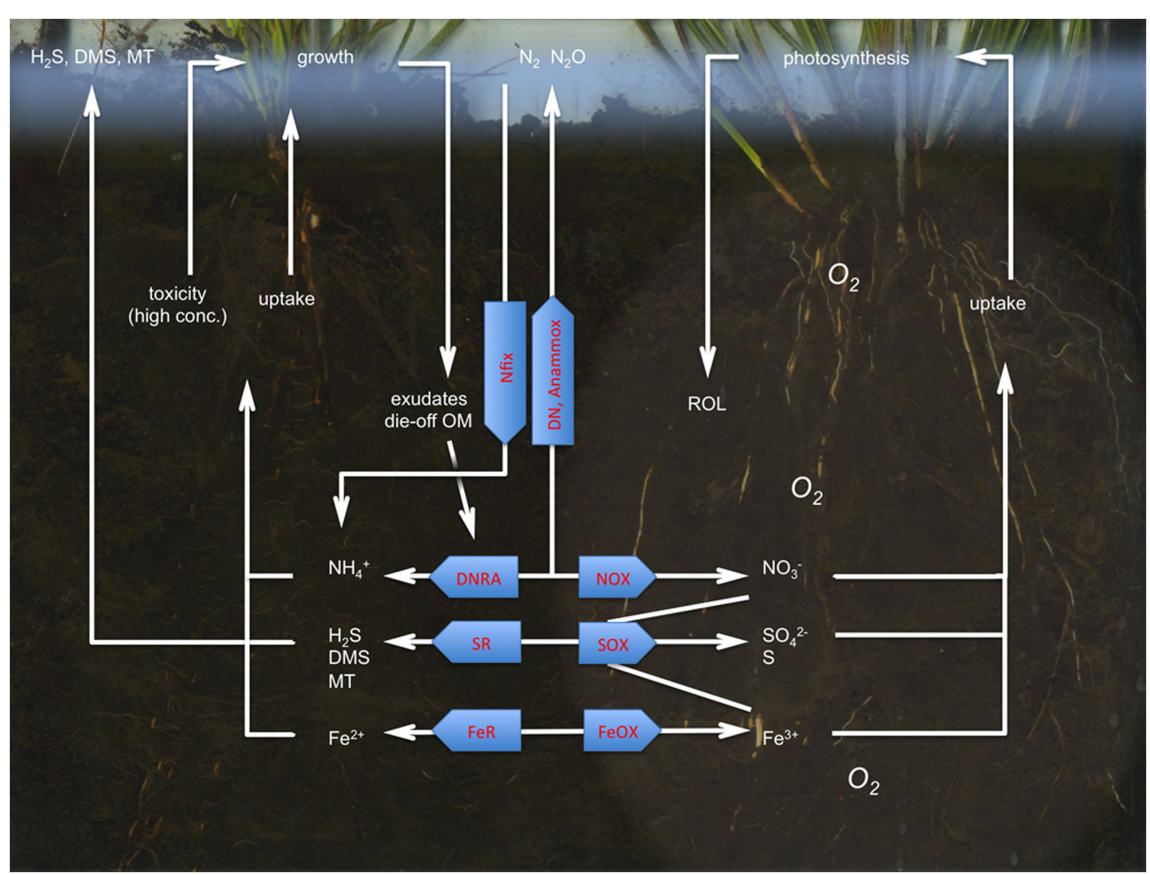

FIGURE 4 | Microbe-plant interactions in the biogeochemistry of N, S, and $\mathrm{Fe}$ in wetland soils. Losses of volatile $\mathrm{N}$ and $\mathrm{S}$ compounds to the atmosphere also occur through plant tissues, which has not been depicted here. See text for further explanation. DNRA, dissimilatory nitrate reduction to ammonium; SR, sulfate reduction; FeR, iron reduction, NOX, N oxidation to $\mathrm{NO}_{x}$, SOX, S oxidation; FeOX, Fe oxidation; DN, denitrification; Nfix, $\mathrm{N}_{2}$ fixation; Anammox, anaerobic ammonium oxidation; ROL, radial oxygen loss (by roots).

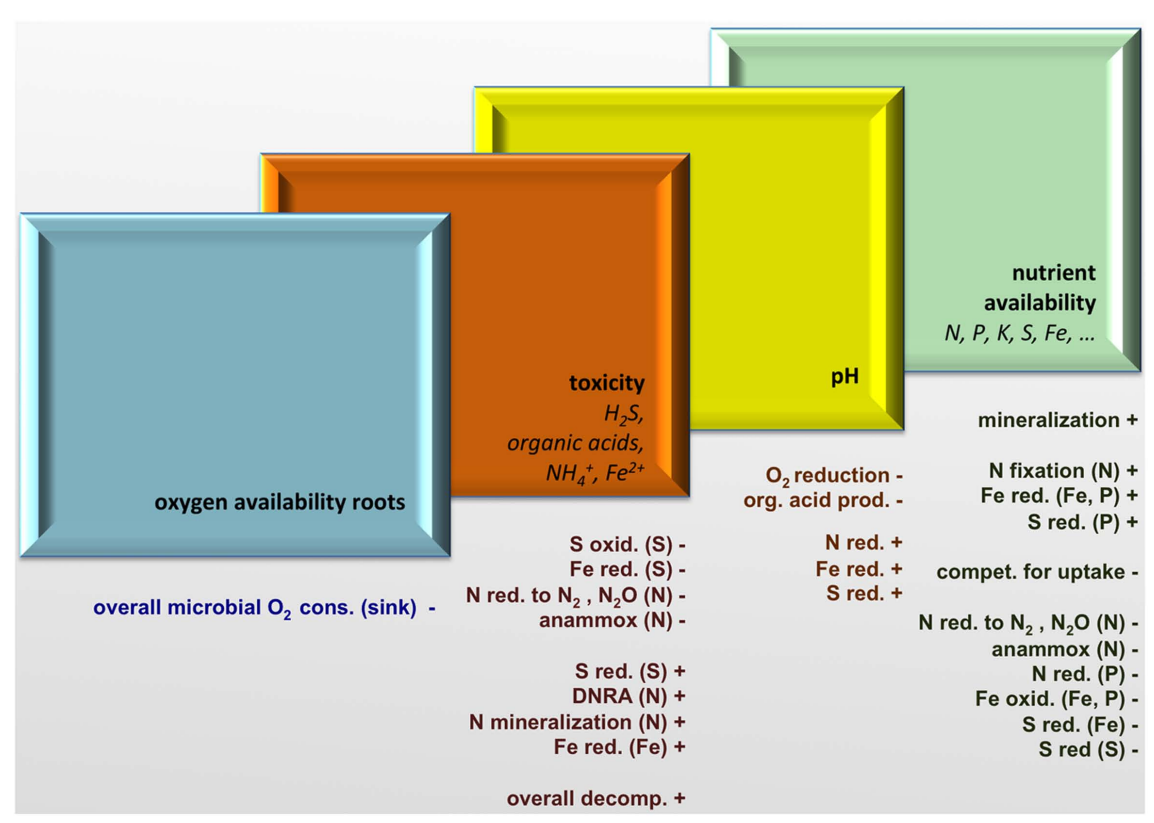

FIGURE 5 | Four filters created by microbial activities related to N, S, and Fe biogeochemistry influence the occurrence and functioning of wetland plant species, and their interspecific competition. A positive influence on the parameter mentioned on the filter frame is denoted by + , a negative by - . 
the role of $\mathrm{Fe}$ in regulating vegetation composition, $\mathrm{P}$ availability, and sulfide detoxification in wetlands has been changed (Lamers et al., in press). In combination with increased inputs of N, S, and $\mathrm{P}$, large-scale changes of wetland communities (microbial communities and their vegetation) have resulted, and ecosystem services such as $\mathrm{C}$ sequestration, flood protection, water storage, and biodiversity have been altered. The resilience of ecosystems to global change depends to a large extent on the responses microbial communities and their positive and negative feed-backs with respect to these changes. For this reason, changes in microbial composition and activity should be incorporated in ecosystem models (Treseder et al., 2011).

\section{GENERAL CONCLUSION}

The biogeochemical cycling of N, S, and Fe shows strong interactions in microbe-plant communities at various levels, from rhizosphere to landscape (Figure 4). The composition and activity of microbial communities dictate vegetation composition to a large extent by their strong effects on four important drivers (below-ground environmental filters) of the growth, composition, and biodiversity of wetland vegetation, namely root oxygen availability, phytotoxicity, $\mathrm{pH}$, and nutrient availability (Figure 5). Microbe-plant interactions provide challenging and complex new topics for highly interesting ecological research carried out by a consortium of specialists. In addition to correlative research, experimental research in the field and lab is essential to determine causal relationships. The fast development of new and much cheaper molecular techniques opens up a whole new world of rhizosphere research, in which basic and applied ecological issues on plant-microbe communities (Table 1) can be addressed that were impossible or much more difficult in the recent past. In addition, new students should be challenged and trained to address ecological topics in this multi-disciplinary way. Especially on a rapidly changing globe, it is vital that both microbiologists and plant ecologists meet in the hidden half of plant communities to better understand ecosystem changes at multiple levels.

Table 1 | Examples of fundamental and applied ecological challenges regarding plant-microbe communities in wetlands (and other ecosystem types).

\section{LANDSCAPE/ECOSYSTEM}

Interrelations among geohydrology, microbial communities, and vegetation development

Biogeochemical controls of carbon dynamics (primary production-decomposition feed-backs)

Impacts of anthropogenic hydrological changes (e.g., change from discharge of Fe-rich groundwater to recharge) on the interactions between microbial communities and vegetation

Pollution effects (e.g., $\mathrm{N}$ and $\mathrm{S}$ pollution groundwater, $\mathrm{P}$ pollution surface water, increased airborne $\mathrm{N}$ and $\mathrm{S}$ ) on plant-microbe interactions

Climate change (e.g., changes in precipitation and temperature patterns), effects on landscape biogeochemistry

Microbial ecology in conservation biology

Microbial ecology in restoration ecology

\section{ECOSYSTEM}

Role of microorganisms in vegetation succession and development

Role of vegetation in the succession and dynamics of microbial communities

Role of soil heterogeneity (e.g., nutrients, organic substrates, toxins, temperature, electron acceptors) in the functioning of plant-microbe communities, including the competition among microorganisms

Biodiversity in plant-microbe communities: niche differentiation, disturbance, fluctuation, neutral theory

Biodiversity of plant-microbe communities and ecosystem functioning and resilience

Microbial consortia in three-dimensional rhizosphere gradients

Rhizosphere community dynamics (e.g., diurnal, seasonal)

Plant host specificity of microbial communities and symbionts (e.g., comparison of species, same species under different environmental conditions)

Competition among plants based on their microbial communities (e.g., rhizosphere community as a plant trait)

Competition among microbes as a result of plant community changes

Competition for nutrients between microbes and plants, community effects

Dispersal of microbes and plants

Climate change effects (temperature, rainfall, $\mathrm{CO}_{2}$ ) on plant-microbe interactions

Optimization of water purification in constructed wetlands based on the manipulation of soil-plant-microbe interactions

\section{ECOPHYSIOLOGY}

Microbial controls on nutrient and water uptake by plants (including costs and benefits of mycorrhiza)

Gas (e.g., $\mathrm{CO}_{2}, \mathrm{CH}_{4}, \mathrm{~N}_{2}, \mathrm{~N}_{2} \mathrm{O}$ ) exchange in the plant-microbe continuum; effects of methane oxidizing symbionts on photosynthesis (e.g., Sphagnum mosses)

Selective root placement and microbial communities

Dynamics in anaerobiosis and microbe-plant interactions

Microbial manipulation of phytotoxic compounds (including agricultural crops, e.g., $\mathrm{H}_{2} \mathrm{~S}$ oxidation by symbiotic $\mathrm{S}$ oxidizers)

Generation of electricity in constructed wetlands

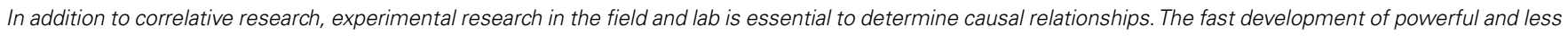
expensive molecular techniques will strongly facilitate comparative and experimental community studies. 


\section{REFERENCES}

Aerts, R., and Chapin, F. S. (2000). The mineral nutrition of wild plants revisited: a re-evaluation of processes and patterns. Adv. Ecol. Res. 30, 1-67.

Armstrong, J., Afreen-Zobayed, F., and Armstrong, W. (1996). Phragmites die-back: sulphide- and acetic acidinduced bud and root death, lignifications, and blockages within aeration and vascular systems. New Phytol. 134, 601-614.

Armstrong, W. (1978). "Root aeration in the wetland condition," in Plant Life in Anaerobic Environments, eds D. D. Hook and R. M. M. Crawford (Ann Arbor, MI: Ann Arbor Science Publishers), 269-297.

Arth, I., Frenzel, P., and Conrad, R. (1998). Denitrification coupled to nitrification in the rhizosphere of rice. Soil Biol. Biochem. 30, 509-515.

Azzoni, R., Giordani, C., Bartoli, M., Welsh, D. T., and Viaroli, P. (2001). Iron, sulphur and phosphorus cycling in the rhizosphere sediments of a eutrophic Ruppia cirrhosa meadow (Valle Smarlacca, Italy). J. Sea Res. 45, 15-26.

Batty, L. C., Baker, A. J. M., Wheeler, B. D., and Curtis, C. D. (2000). The effect of $\mathrm{pH}$ and plaque on the uptake of $\mathrm{Cu}$ and $\mathrm{Mn}$ in Phragmites australis (Cav.) Trin ex. Steudel. Ann. Bot. 86, 647-653.

Bienfait, H. F. (1989). Prevention of stress in iron-metabolism of plants. Acta Bot. 38, 105-129.

Bobbink, R., Hornung, M., and Roelofs, J. G. M. (1998). The effects of airborne nitrogen pollutants on species diversity in natural and semi-natural European vegetation. J. Ecol. 86, 717-738.

Bodelier, P. L. E. (2003). "Interactions between oxygen-releasing roots and microbial processes in flooded soils and sediments," in Root Ecology, eds H. De Kroon and E. J. W. Visser (Berlin: Springer-Verlag), 331-362.

Bodelier, P. L. E. (2011). Toward understanding, managing, and protecting microbial ecosystems. Front. Microbiol. 2:80. doi:10.3389/fmicb.2011.00080

Bodelier, P. L. E., Duyts, H., Blom, C. W. P. M., and Laanbroek, H. J. (1998). Interactions between nitrifying and denitrifying bacteria in gnotobiotic microcosms planted with the emergent macrophyte Glyceria maxima. FEMS Microbiol. Ecol. 25, 63-78.

Bodelier, P. L. E., Libochant, J. A., Blom, C. W. P. M., and Laanbroek, H. J. (1996). Dynamics of nitrification and denitrification in root-oxygenated sediments and adaptation of ammonia-oxidizing bacteria to low-oxygen or anoxic habitats. Appl. Environ. Microbiol. 62, 4100-4107.

Bodelier, P. L. E., Sorrell, B., Drake, H. L., Küsel, K., Hurek, T. P., ReinholdHurek, B., Lovell, C., Megonigal, P., and Frenzel, P. (2006). "Ecological aspects of microbes and microbial communities inhabiting the rhizosphere of wetland plants," in Wetlands as a Natural Resource, Vol. 2, eds R. Bobbink, B. Beltman, J. T. A. Verhoeven, and D. F Whigman (New York: Springer Verlag), 205-238.

Bodelier, P. L. E., Wijlhuizen, A. G., Blom, C. W. P. M., and Laanbroek, H. J. (1997). Effects of photoperiod on growth of and denitrification by Pseudomonas chlororaphis in the root zone of Glyceria maxima, studied in a gnotobiotic microcosm. Plant Soil 190, 91-103.

Bolan, N. S. (1991). A critical review on the role of mycorrhizal fungi in the uptake of phosphorus by plants. Plant Soil 134, 189-207.

Boone, R. D., Nadelhoffer, K. J., Canary, J. D., and Kayeet, J. P. (1998). Roots exert a strong influence on the temperature sensitivity of soil respiration. Nature 396, 570-572.

Bragazza, L., and Freeman, C. (2007). High nitrogen availability reduces polyphenol content in Sphagnum peat. Sci. Total Environ. 377, 439-443.

Brune, A., Frenzel, P., and Cypionka, H. (2000). Life at the oxic-anoxic interface: microbial activities and adaptations. FEMS Microbiol. Rev. 24, 691-710.

Burgin, A. J., and Hamilton, S. K. (2008). $\mathrm{NO} 3$ - driven $\mathrm{SO}_{4}{ }^{-}$production in freshwater ecosystems: implications for $\mathrm{N}$ and S cycling. Ecosystems 11, 908-922.

Burgin, A. J., and Hamilton, S. K. (2007). Have we overemphasized the role of denitrification in aquatic ecosystems? A review of nitrate removal pathways. Front. Ecol. Environ. 5, 89-96.

Callaway, R. M. (1995). Positive interactions among plants. Bot. Rev. 61, 306-349.

Canadell, J., Jackson, R. B., Ehleringer, J. R., Mooney, H. A., Sala, O. E., and Schulze, E.-D. (1996). Maximum rooting depth of vegetation types at the global scale. Oecologia 108, 583-595.

Caraco, N. F., Cole, J. J., and Likens, G. E. (1989). Evidence for sulphatecontrolled phosphorus release from sediments of aquatic systems. Nature 341, 316-318.
Carpenter, S. R., Caraco, N. F., Correll, D. L., Howarth, R. W., Sharpley, A. N., and Smith, V. H. (1998). Nonpoint pollution of surface waters with phosphorus and nitrogen. Ecol. Appl. 8, 559-568.

Clymo, R. S., Turunen, J., and Tolonen, K. (1998). Carbon accumulation in peatland. Oikos 81, 368-388.

Coleman, M. L., Hedrick, D. B., Lovley, D. R., White, D. C., and Pye, K. (1993). Reduction of Fe(III) in sediments by sulfate-reducing bacteria. Nature 361, 436-438.

Colmer, T. D. (2003). Long-distance transport of gases in plants: a perspective on internal aeration and radial oxygen loss from roots. Plant Cell Environ. 26, 17-36.

Conrad, R., and Frenzel, P. (2002). "Flooded soils," in Encyclopedia of Environmental Microbiology, ed. G. Bitton (New York: Wiley), 1316-1333.

Dakora, F. D., and Phillips, D. A (2002). Root exudates as mediators of mineral acquisition in lownutrient environments. Plant Soi 245, 35-47.

De Boer, W., and Kowalchuk, G. A. (2001). Nitrification in acid soils: micro-organisms and mechanisms. Soil Biol. Biochem. 33, 853-866.

De Kroon, H., Hendriks, M., Van Ruijven, J., Ravenek, J., Padilla, F. M., Jongejans, E., Visser, E. J. W., and Mommer, L. (2012). Root responses to nutrients and soil biota: drivers of species coexistence and ecosystem productivity. J. Ecol. 100, 6-15.

Dijkshoorn, W., and van Wijk, A. L. (1967). Sulphur requirements of plants as evidenced by sulphurnitrogen ratio in organic matter. A review of published data. Plant Soil 26, 129-157.

Emerson, D., Weiss, J. V., and Megonigal, J. P. (1999). Iron-oxidizing bacteria are associated with ferric hydroxide precipitates (Fe-plaque) on the roots of wetland plants. Appl. Environ. Microbiol. 65 2758-2761.

Frederiksen, M. S., Holmer, M., Borum, J., and Kennedy, H. (2006). Temporal and spatial variation of sulfide invasion in eelgrass (Zostera marina) as reflected by its sulfur isotopic composition. Limnol. Oceanogr. 51, 2308-2318.

Freeman, C., Ostle, N., and Kang, H. (2001). An enzymic "latch" on a global carbon store - a shortage of oxygen locks up carbon in peatlands by restraining a single enzyme. Nature 409, 149-149.

Frenzel, P., Rothfuss, F., and Conrad, R. (1992). Oxygen profiles and methane turnover in a flooded rice mesocosm. Biol. Fert. Soils 14, 84-89.

Frenzel, P., Bosse, U., and Janssen, P. H. (1999). Rice roots and methanogenesis in a paddy soil: ferric iron as an alternative electron acceptor in the rooted soil. Soil Biol. Biochem. 31, 421-430.

Fritz, C., Pancotto, V. A., Elzenga, J. T. M., Visser, E. J. W., Grootjans, A. P., Pol, A., Iturraspe, R., Roelofs, J. G. M., and Smolders, A. J. P. (2011). Zero methane emission bogs: extreme rhizosphere oxygenation by cushion plants in Patagonia. New Phytol. 190, 398-408.

Geurts, J. J. M., Sarneel, J. M., Willers, B. J. C., Roelofs, J. G. M., Verhoeven, J. T. A., and Lamers, L. P. M. (2009). Interacting effects of sulphate pollution, sulphide toxicity and eutrophication on vegetation development in fens: a mesocosm experiment. Environ. Pollut. 157, 2072-2081.

Geurts, J. J. M., Smolders, A. J. P., Verhoeven, J. T. A., Roelofs, J. G. M., and Lamers, L. P. M. (2008). Sediment $\mathrm{Fe}: \mathrm{PO}(4)$ ratio as a diagnostic and prognostic tool for the restoration of macrophyte biodiversity in fen waters. Freshw. Biol. 53, 2101-2116.

Gilbert, G. S. (2002). Evolutionary ecology of plant diseases in natural ecosystems. Annu. Rev. Phytopathol. 40, 13-43.

Golterman, H. L. (2001). Phosphate release from anoxic sediments or "What did Mortimer really write?" Hydrobiologia 450, 99-106.

Haaijer, S. C. M., Lamers, L. P. M., Smolders, A. J. P., Jetten, M. S. M., and Op den Camp, H. J. M. (2007). Iron sulfide and pyrite as potential electron donors for microbial nitrate reduction in freshwater wetlands. Geomicrobiol. J. 24, 391-401.

Haaijer, S. C. M., Van der Welle, M. E. W., Schmid, M. C., Lamers, L. P. M. Jetten, M. S. M., and Op den Camp, H. J. M. (2006). Evidence for the involvement of betaproteobacterial Thiobacilli in the nitrate-dependent oxidation of iron sulfide minerals. FEMS Microbiol. Ecol. 58, 439-448.

Hajek, T., Ballance, S., Limpens, J., Zijlstra, M., and Verhoeven, J. T. A. (2011). Cell-wall polysaccharides play an important role in decay resistance of Sphagnum and actively depressed decomposition in vitro. Biogeochemistry 103, 45-57.

Hansel, C. M., Fendorf, S., Sutton, S., and Newville, M. (2001). Characterization of Fe plaque and associated metals on the roots of mine-waste impacted aquatic plants. Environ. Sci. Technol. 35, 3863-3868. 
Hanson, P. J., Edwards, N. T., Garten, C. T., and Andrews, J. A. (2000). Separating root and soil microbial contributions to soil respiration: a review of methods and observations. Biogeochemistry 48, 115-146.

Hell, R., and Stephan, U. W. (2003). Iron uptake, trafficking and homeostasis in plants. Planta 216, 541-551.

Hobbie, S. E. (1992). Effects of plantspecies on nutrient cycling. Trends Ecol. Evol. (Amst.) 7, 336-339.

Hodge, A. (2004). The plastic plant: root responses to heterogeneous supplies of nutrients. New Phytol. 162, 9-24.

Hodge, A., Robinson, D., and Fitter, A. (2000). Are microorganisms more effective than plants at competing for nitrogen? Trends Plant Sci. 5, 304-308.

Holmer, M., Pedersen, O., KrauseJensen, D., Olesen, B., Petersen, M. H., Schopmeyer, S., Koch, M., Lomstein, B. A., and Jensen, H. S. (2009). Sulfide intrusion in the tropical seagrasses Thalassia testudinum and Syringodium filiforme. Estuar. Coast. Shelf Sci. 85, 319-326.

$\mathrm{Hu}$, B.-I., Rush, D., van der Biezen, E., Zheng, P., Van Mullekom, M., Schouten, S., Damste, J. S. S., Smolders, A. J. P., Jetten, M. S. M., and Kartal, B. (2011). New anaerobic, ammonium-oxidizing community enriched from peat soil. Appl. Environ. Microbiol. 77, 966-971.

Huisman, J., and Weissing, F. J. (1999). Biodiversity of plankton by species oscillations and chaos. Nature 402, 407-410.

Hutchings, M. J., and De Kroon, H. (1994). Foraging in plants - the role of morphological plasticity in resource acquisition. Adv. Ecol. Res. 25, 159-238.

Jackson, M. B., and Armstrong, W. (1999). Formation of aerenchyma and the processes of plant ventilation in relation to soil flooding and submergence. Plant Biol. 1, 274-287.

Jetten, M. S. M. (2008). The microbial nitrogen cycle. Environ. Microbiol. 10, 2903-2909.

Jetten, M. S. M., Strous, M., Van de Pas-Schoonen, K. T., Schalk, J., Van Dongen, U., Van de Graaf, A. A., Logemann, S., Muyzer, G., Van Loosdrecht, M. C. M., and Kuenen, J. G. (1998). The anaerobic oxidation of ammonium. FEMS Microbiol. Rev. 22, 421-437.

Jones, D. L. (1998). Organic acids in the rhizosphere - a critical review. Plant Soil 205, 25-44.

Joshi, M. M., and Hollis, J. P. (1977). Interaction of Beggiatoa and rice plant - detoxification of hydrogensulfide in rice rhizosphere. Science 195, 179-180.

Kalbitz, K., Solinger, S., Park, J. H., Michalzik, B., and Matzner, E. (2000). Controls on the dynamics of dissolved organic matter in soils: a review. Soil Sci. 165, 277-304.

Khadem, A. F., Pol, A., Jetten, M. S. M., and Opden Camp, H. J. M. (2010). Nitrogen fixation by the verrucomicrobial methanotroph "Methylacidiphilum fumariolicum" SolV. Microbiology 156, 1052-1059.

Kneip, C., Lockhart, P., Voß, C., and Maier, U.-G. (2007). Nitrogen fixation in eukaryotes - new models for symbiosis. BMC Evol. Biol. 7, 55. doi:10.1186/1471-2148-7-55

Koch, M. S., Mendelssohn, I. A., and McKee, K. L. (1990). Mechanism for the hydrogen sulfide-induced growth limitation in wetland macrophytes. Limnol. Oceanogr. 35, 399-408.

Koch, M. S., Schopmeyer, S. A., KyhnHansen, C., and Madden, C. J. (2007). Synergistic effects of high temperature and sulfide on tropical seagrasses. J. Exp. Mar. Biol. Ecol. 341, 91-101.

Laan, P., Berrevoets, M. J., Lythe, S., Armstrong, W., and Blom, C. W. P. M. (1989). Root morphology and aerenchyma formation as indicators of the flood-tolerance of Rumex species. J. Ecol. 77, 693-703.

Lambers, H. (1976). Respiration and NADH-oxidation of the roots of flood-tolerant and flood-intolerant Senecio species as affected by anaerobiosis. Physiol. Plant. 37, 117-122.

Lamers, L. P. M., Falla, S. J., Samborska, E. M., Van Dulken, L. A. R., Van Hengstum, G., and Roelofs, J. G. M. (2002a). Factors controlling the extent of eutrophication and toxicity in sulfate-polluted freshwater wetlands. Limnol. Oceanogr. 47, 585-593.

Lamers, L. P. M., Smolders, A. J. P., and Roelofs, J. G. M. (2002b). The restoration of fens in the Netherlands. Hydrobiologia 478, 107-130.

Lamers, L. P. M., Tomassen, H. B. M., and Roelofs, J. G. M. (1998). Sulfateinduced eutrophication and phytotoxicity in freshwater wetlands. Environ. Sci. Technol. 32, 199-205.

Lamers, L. P. M., Vile, M. A., Grootjans, A. P., Acreman, M. C., Van Diggelen, R., Evans, M. G., Richardson, C. J., Rochefort, L., Roelofs, J. G. M., and Smolders, A. J. P. (in press). "The restoration of fens and fen waters in agricultural areas: from trial and error to predictability," in Restoring Peatlands - Delivering Multiple
Benefits, eds A. Bonn, T. Allott, M. Evans, H. Joosten, and R. Stoneman (Cambridge University Press).

Larcher, W. (2003). Physiological Plant Ecology, 4th Edn. Berlin: Springer.

Leininger, S., Urich, T., Schloter, M., Schwark, L., Qi, J., Nicol, G. W., Prosser, J. I., Schuster, S. C., and Schleper, C. (2006). Archaea predominate among ammoniaoxidizing prokaryotes in soils. Nature 442, 806-809.

Loeb, R., Lamers, L. P. M., and Roelofs, J. G. M. (2008). Prediction of phosphorus mobilisation in inundated floodplain soils. Environ. Pollut. 156, 325-331.

Lomans, B. P., Van der Drift, C., Pol, A. and Op den Camp, H. J. M. (2002). Microbial cycling of volatile organic sulfur compounds. Cell. Mol. Life Sci. 59, 575-588.

Lovley, D. R. (2006). Bug juice: harvesting electricity with microorganisms. Nat. Rev. Microbiol. 4, 497-508.

Lovley, D. R., Holmes, D. E., and Nevin, K. P. (2004). Dissimilatory Fe(III) and $\mathrm{Mn}(\mathrm{IV})$ reduction. Adv. Microb. Physiol. 49, 219-286.

Lovley, D. R., and Phillips, E. J. P. (1988). Novel mode of microbial energy-metabolism - organiccarbon oxidation coupled to dissimilatory reduction of iron and manganese. Appl. Environ. Microbiol. 54, 1472-1480.

Lucassen, E. C. H. E. T., Bobbink, R., Smolders, A. J. P., Van der Ven, P. J. M., Lamers, L. P. M., and Roelofs, J. G. M. (2003). Interactive effects of low $\mathrm{pH}$ and high ammonium levels responsible for the decline of Cirsium dissectum (L.) Hill. Plant Ecol. 165, 45-52.

Lucassen, E. C. H. E. T., Smolders, A. J. P., and Roelofs, J. G. M. (2000). Increased groundwater levels cause iron toxicity in Glyceria fluitans (L.). Aquat. Bot. 66, 321-327.

Lucassen, E. C. H. E. T., Smolders, A. J. P., Van der Salm, A. L., and Roelofs, J. G. M. (2004). High groundwater nitrate concentrations inhibit eutrophication of sulphaterich freshwater wetlands. Biogeochemistry 67, 249-267.

Marschner, H. (1995). Mineral Nutrition of Higher Plants, 2nd Edn. London: Academic Press.

McKee, K. L., Mendelssohn, I. A., and Hester, M. W. (1988). Reexamination of pore water sulfide concentrations and redox potentials near the aerial roots of Rhizophora mangle and Avicennia germinans. Am. J. Bot. 75, 1352-1359.

Neubauer, S. C., Givler, K., Valentine, S. K., and Megonigal, J. P.
(2005). Seasonal patterns and plantmediated controls of subsurface wetland biogeochemistry. Ecology 86, 3334-3344.

Ohle, W. (1954). Sulfat als "Katalysator" des limbischen Stoffkreislaufes. Vom Wasser 21, 13-32.

Paul, E. A., and Clark, F. E. (1989). Soil Microbiology and Biochemistry. San Diego: Academic Press Inc.

Pester, M., Knorr, K.-H., Friedrich, M. W., Wagner, M., and Loy, A. (2012). Sulfate-reducing microorganisms in wetlands - fameless actors in carbon cycling and climate change. Front. Microbiol. 3:1. doi:10.3389/fmicb.2012.00072

Rabaey, K., Rodriguez, J., Blackall, L. L., Keller, J., Gross, P., Batstone, D., Verstraete, W., and Nealson, K. H. (2007). Microbial ecology meets electrochemistry: electricity-driven and driving communities. ISME J. 1 , 9-18.

Raven, J. A., and Scrimgeour, C. M. (1997). The influence of anoxia on plants of saline habitats with special reference to the sulphur cycle. Ann. Bot. 79, 79-86.

Read, D. J., and Perez-Moreno, J. (2003). Mycorrhizas and nutrient cycling in ecosystems - a journey towards relevance? New Phytol. 157, 475-492.

Reddy, K. R., Patrick, W. H., and Lindau, C. W. (1989). Nitrificationdenitrification at the plant rootsediment interface in wetlands. Limnol. Oceanogr. 34, 1004-1013.

Reed, S. C., Cleveland, C. C., and Townsend, A. R. (2011). Functional ecology of free-living nitrogen fixation: a contemporary perspective. Annu. Rev. Ecol. Evol. Syst. 42, 489-512.

Richardson, C. J. (1985). Mechanisms controlling phosphorus retention capacity in freshwater wetlands. Science 228, 1424-1427.

Ripl, W. (2010). "Restoration of eutrophic lakes by sediment treatment," in Restoration of Lakes, Streams, Floodplains, and Bogs in Europe, ed. M. Eiseltová (Amsterdam: Springer), 77-84.

Robinson, D., Hodge, A., and Fitter, A. (2003). "Constraints on the form and function of root systems," in Root Ecology, eds H. De Kroon and E. J. W. Visser (Berlin: SpringerVerlag), 1-32.

Roden, E. E., and Edmonds, J. W. (1997). Phosphate mobilization in ironrich anaerobic sediments: microbial $\mathrm{Fe}(\mathrm{III})$ oxide reduction versus ironsulfide formation. Arch. Hydrobiol. 139, 347-378.

Roelofs, J. G. M., Schuurkes, J., and Smits, A. J. M. (1984). Impact 
of acidification and eutrophication on macrophytes communities in soft waters. 2. Experimental studies. Aquat. Bot. 18, 389-411.

Scheffer, F., and Schachtschabel, P. (2002). Lehrbuch der Bodenkunde. Heidelberg: Spektrum Akademischer Verlag.

Schenk, M., and Wehrmann, J. (1979). Influence of ammonia in nutrient solution on growth and metabolism of cucumber plants. Plant Soil 52, 403-414.

Schlesinger, W. H. (1997). Biogeochemistry: An Analysis of Global Change. San Diego: Academic Press.

Schmidt, W. (1999). Mechanisms and regulation of reduction-based iron uptake in plants. New Phytol. 141, 1-26.

Shah, J., Nagpal, T., Johnson, T., Amann, M., Carmichael, G., Foell, W., Green, C., Hettelingh, L. P., Hordijk, L., Li, J., Peng, C., Pu, Y. F., Ramankutty, R., and Streets, D. (2000). Integrated analysis for acid rain in Asia: policy implications and results of RAINSASIA model. Annu. Rev. Environ. Resour. 25, 339-375.

Smith, F. A., and Smith, S. E. (1997). Tansley review no. 96 structural diversity in (vesicular)-arbuscular mycorrhizal symbioses. New Phytol. 137, 373-388.

Smolders, A. J. P., Lamers, L. P. M., Lucassen, E. C. H. E. T., Van der Velde, G., and Roelofs, J. G. M. (2006). Internal eutrophication: how it works and what to do about it - a review. Chem. Ecol. 22, 93-111.

Smolders, A. J. P., Lucassen, E. C. H. E. T., Bobbink, R., Roelofs, J. G. M., and Lamers, L. P. M. (2010). How nitrate leaching from agricultural lands provokes phosphate eutrophication in groundwater fed wetlands: the sulphur bridge. Biogeochemistry 98, 1-7.

Smolders, A. J. P., Lucassen, E. C. H. E. T., and Roelofs, J. G. M. (2002). The isoetid environment: biogeochemistry and threats. Aquat. Bot. 73, 325-350.

Smolders, A. J. P., and Roelofs, J. G. M. (1993). Sulfate-mediated iron limitation and eutrophication in aquatic systems. Aquat. Bot. 46, 247-253.

Smolders, A. J. P., and Roelofs, J. G. M. (1996). The roles of internal iron hydroxide precipitation, sulphide toxicity and oxidizing ability in the survival of Stratiotes aloides roots at different iron concentrations in sediment pore water. New Phytol. 133, 253-260.

Snowden, R. E. D., and Wheeler, B. D. (1995). Chemical changes in selected wetland plant species with increasing $\mathrm{Fe}$ supply, with specific reference to root precipitates and Fe tolerance. New Phytol. 131, 503-520.

Sperber, J. I. (1958). Release of phosphate from soil minerals by hydrogen sulphide. Nature 181, 934.

Stevens, C. J., Manning, P., Van den Berg, L. J. L., De Graaf, M. C. C., Wamelink, G. W. W., Boxman, A. W., Bleeker, A., Vergeer, P., Arroniz-Crespo, M., Limpens, J., Lamers, L. P. M., Bobbink, R., and Dorland, E. (2011). Ecosystem responses to reduced and oxidised nitrogen inputs in European terrestrial habitats. Environ. Pollut. 159, 665-676.

Tanaka, A., Ranjit, P., Mulleriyawa, R. P., and Yasu, T. (1968). Possibility of hydrogen sulfide induced iron toxicity of the rice plant. Soil Sci. Plant Nutr. 14, 1-6.

Taylor, G. J., Crowder, A. A., and Rodden, R. (1984). Formation and morphology of an iron plaque on the roots of Typha latifolia L. grown in solution culture. Am. J. Bot. 71, 666-675.

Thamdrup, B., Fossing, H., and Jorgensen, B. B. (1994). Manganese, iron, and sulfur cycling in a coastal marine sediment, Aarhus Bay, Denmark. Geochim. Cosmochim. Ac. 58, 5115-5129.

Thurston, R. V., Russo, R. C., and Vinogradov, G. A. (1981). Ammonia toxicity to fishes - effect of $\mathrm{pH}$ on the toxicity of the un-ionized ammonia species. Environ. Sci. Technol. 15, 837-840.

Tomassen, H. B. M., Smolders, A. J. P., Lamers, L. P. M., and Roelofs, J. G. M. (2003). Stimulated growth of Betula pubescens and Molinia caerulea on ombrotrophic bogs: role of high levels of atmospheric nitrogen deposition. J. Ecol. 91, 357-370.

Treseder, K. K., Balser, T. C., Bradford, M. A., Brodie, E. L., Dubinsky, E. A., Eviner, V. T., Hofmockel, K. S., Lennon, J. T., Uri, Y., Levine, U. Y., MacGregor, B. J., Pett-Ridge, J., and Waldrop, M. P. (2011). Integrating microbial ecology into ecosystem models: challenges and priorities. Biogeochemistry. doi:10.1007/s10533-011-9636-9635

Van den Berg, L. J. L., Dorland, E., Vergeer, P., Hart, M. A. C., Bobbink, R., and Roelofs, J. G. M. (2005). Decline of acid-sensitive plant species in heathland can be attributed to ammonium toxicity in combination with low $\mathrm{pH}$. New Phytol. 166, 551-564.
Van den Heuvel, R. N., Bakker, S. E., Jetten, M. S. M., and Hefting, M. M. (2011). Decreased N2O reduction by low soil $\mathrm{pH}$ causes high $\mathrm{N} 2 \mathrm{O}$ emissions in a riparian ecosystem. Geobiology 9, 294-300.

Van den Heuvel, R. N., Hefting, M. M., Tan, N. C. G., Jetten, M. S. M., and Verhoeven, J. T. A. (2009). $\mathrm{N} 2 \mathrm{O}$ emission hotspots at different spatial scales and governing factors for small scale hotspots. Sci. Total Environ. 407, 2325-2332.

Van der Heide, T., Smolders, A. J. P., Lamers, L. P. M., Van Katwijk, M. M., and Roelofs, J. G. M. (2010). Nutrient availability correlates with bicarbonate accumulation in marine and freshwater sediments empirical evidence from pore water analyses. Appl. Geochem. 25, 1825-1829.

Van der Welle, M. E. W., Cuppens, M., Lamers, L. P. M., and Roelofs, J. G. M. (2006). Detoxifying toxicants: interactions between sulfide and iron toxicity in freshwater wetlands. Environ. Toxicol. Chem. 25, 1592-1597.

Vartapetian, B. B., and Jackson, M. B. (1997). Plant adaptations to anaerobic stress. Ann. Bot. 79, 3-20.

Verhoeven, J. T. A., and Toth, E. (1995). Decomposition of Carex and Sphagnum litter in fens - effect of litter quality and inhibition by living tissue-homegenates. Soil Biol. Biochem. 27, 271-275.

Visser, E. J. W., Bögemann, G. M., Van de Steeg, H. M., Pierik, R., and Blom, C. W. P. M. (2000a). Flooding tolerance of Carex species in relation to field distribution and aerenchyma formation. New Phytol. 148, 93-103.

Visser, E. J. W., Colmer, T. D., Blom, C. W. P. M., and Voesenek, L. A. C. J. (2000b). Changes in growth, porosity, and radial oxygen loss from adventitious roots of selected mono- and dicotyledonous wetland species with contrasting types of aerenchyma. Plant Cell Environ. 23, 1237-1245.

Vitousek, P. M., Aber, J. D., Howarth, R. W., Likens, G. E., Matson, P. A., Schindler, D. W., Schlesinger, W. H., and Tilman, D. G. (1997). Human alteration of the global nitrogen cycle: sources and consequences. Ecol. Appl. 7, 737-750.

Vitousek, P. M., and Howarth, R. W. (1991). Nitrogen limitation on land and in the sea. Biogeochemistry 13, 87-115.

Voesenek, L. A. C. J., Colmer, T. D., Pierik, R., Millenaar, F. F., and Peeters, A. J. M. (2006). How plants cope with complete submergence. New Phytol. 170, 213-226.

Waisel, Y., Eshel, A., and Kafkafi, U. (1996). Plant Roots. The Hidden Half, 2nd Edn. New York: Marcel Dekker.

Weiss, J. V., Emerson, D., and Megonigal, J. P. (2004). Geochemical control of microbial $\mathrm{Fe}(\mathrm{III})$ reduction potential in wetlands: comparison of the rhizosphere to non-rhizosphere soil. FEMS Microbiol. Ecol. 48, 89-100.

Welsh, D. T., Bartoli, M., Nizzoli, D., Castaldelli, G., Riou, S. A., and Viaroli, P. (2000). Denitrification, nitrogen fixation, community primary productivity and inorganic-N and oxygen fluxes in an intertidal Zostera noltii meadow. Mar. Ecol. Prog. Ser. 208, 65-77.

Wetzel, R. G. (2001). Limnology: Rivers and Lakes. San Diego, CA: Academic Press.

Whipps, J. M. (2001). Microbial interactions and biocontrol in the rhizosphere. J. Exp. Bot. 52, 487-511.

Wieder, R. K., Scott, K. D., Kamminga, K., Vile, M. A., Vitt, D. H., Bone, T., Benscoter, B., and Bhatti, J. (2009). Carbon balance recovery in boreal bogs of Continental Western Canada. Glob. Change Biol. 15, 63-81.

Conflict of Interest Statement: The authors declare that the research was conducted in the absence of any commercial or financial relationships that could be construed as a potential conflict of interest.

Received: 10 January 2012; accepted: 04 April 2012; published online: 25 April 2012.

Citation: Lamers LPM, van Diggelen JMH, Op den Camp HJM, Visser EJW, Lucassen ECHET, Vile MA, Jetten MSM, Smolders AJP and Roelofs JGM (2012) Microbial transformations of nitrogen, sulfur, and iron dictate vegetation composition in wetlands: a review. Front. Microbio. 3:156. doi: 10.3389/fmicb.2012.00156

This article was submitted to Frontiers in Terrestrial Microbiology, a specialty of Frontiers in Microbiology.

Copyright (c) 2012 Lamers, van Diggelen, Op den Camp, Visser, Lucassen, Vile, Jetten, Smolders and Roelofs. This is an open-access article distributed under the terms of the Creative Commons Attribution Non Commercial License, which permits non-commercial use, distribution, and reproduction in other forums, provided the original authors and source are credited. 